\title{
Mourning Balliceaux: Towards a biography of a Caribbean island of death, grief and memory
}

\author{
Niall Finneran \\ Department of Archaeology, Anthropology and Geography, University of \\ Winchester, UK \\ Niall.Finneran@winchester.ac.uk (corresponding author)
}

\section{Christina Welch}

Department of Theology, Religions and Philosophy, University of Winchester, UK Christina.Welch@winchester.ac.uk

\begin{abstract}
This contribution considers how a small Caribbean island (Balliceaux, St Vincent and the Grenadines) holds up a mirror to the wider experiences of the Garifuna ('Black Carib') peoples who live on the neighbouring island of St Vincent, and in diasporic communities through the Americas. In the late- $18^{\text {th }}$ Century Balliceaux was the scene of a genocide orchestrated by the British colonial authorities on the Garifuna, and as a consequence it has become an important place of memory for them, yet it also provokes other emotional responses. We start by taking a broadly phenomenological approach to the analysis of islandscape, emphasising its qualities as an embodied as well as physical entity, and then build upon the notion of embodiment using perspectives drawn from psychological studies of grief and grieving through the lens of grief and death studies. We argue that it is only through deploying such a phenomenological perspective to the study of this Caribbean island that we can discern the metaphors employed by the Garifuna in making sense of this island of death, grief and memory. By drawing on their own understandings of Balliceaux as a base for our theorisations, we offer an original theoretical and decolonised approach to thinking about the character, or sense of place, of a small, yet emotionally significant, Caribbean island.
\end{abstract}

Keywords: Balliceaux, Caribbean, Garifuna, islands, phenomenology, St Vincent and the Grenadines, social memory

https://doi.org/10.24043/isj.121 • Received August 2019, accepted January 2020

(C) 2020-Institute of Island Studies, University of Prince Edward Island, Canada.

"Be not afeard. The isle is full of noises,

Sounds, and sweet airs, that give delight and hurt not."

Caliban, The Tempest, William Shakespeare, Act III, Scene 2: 130-131 


\section{Introduction: A troubled islandscape}

The small, uninhabited island of Balliceaux lies just to the east of Bequia, the northernmost of the St Vincent Grenadine islands, north-east of Mustique and some 20 kilometres south-east of the St Vincent capital, Kingstown in the south-eastern Caribbean (Figure 1). In popular imagination the Grenadines conjure images of sandy beaches and beautiful blue seas, of bright sunny skies and yacht-filled harbours. Above all the Grenadines resonate with perceptions of luxury-and indeed the island of Mustique is a private holiday destination beloved of millionaires and royalty. These are islands rife with the symbolism of Caliban's cadences, sweet airs and delights. This is not the case with Balliceaux, however. This is a Grenadine island which is pervaded by a much darker history, and which, as we shall see, embodies (for that is the verb we deploy in this analysis) many complex meanings.
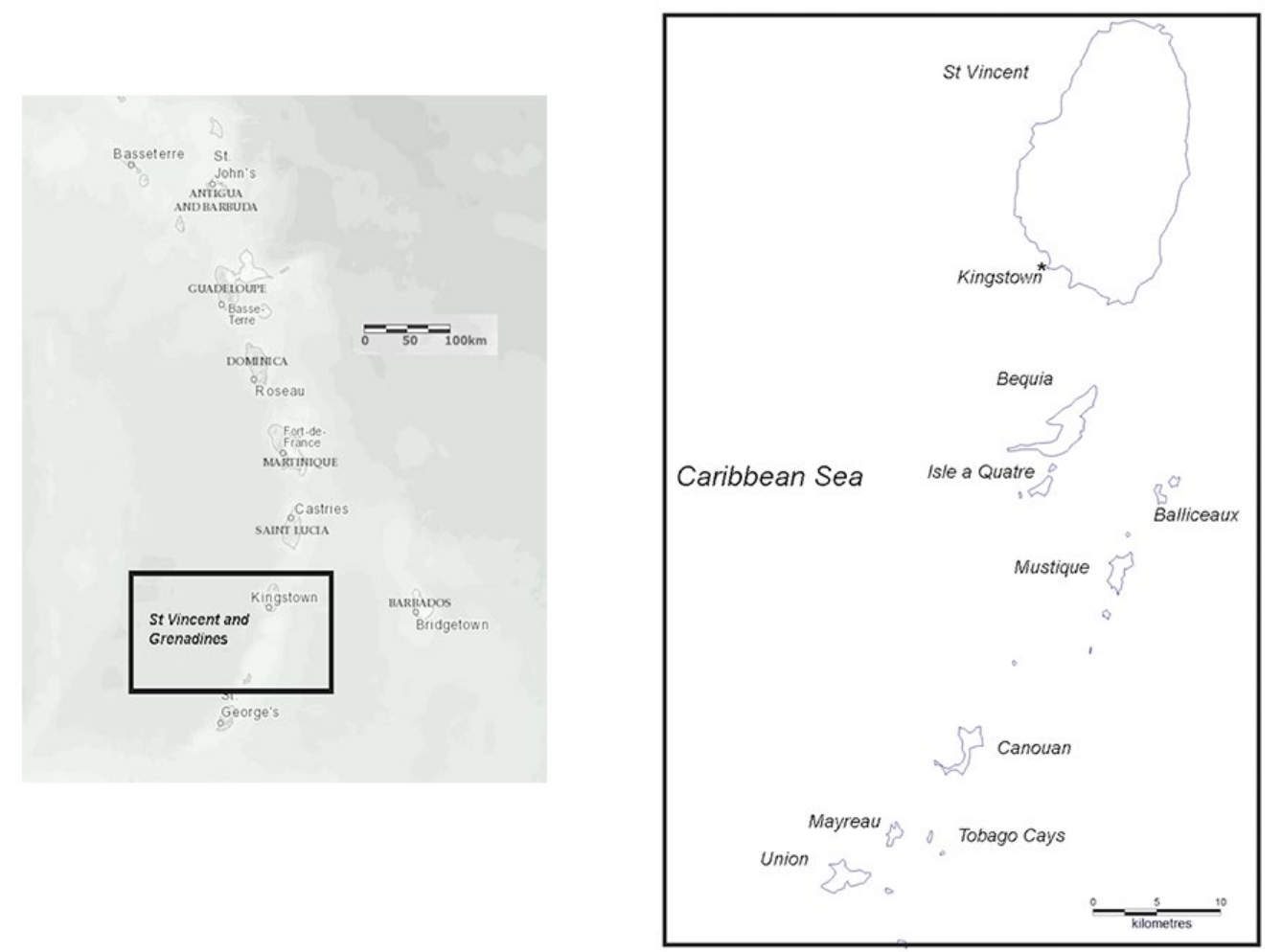

Figure 1. Location of Balliceaux. (C) www.arcgis.com

Balliceaux is an island with a troubled past and an uncertain future. It is a haunted place, an island disturbed by events of the past, and thus a focus of profound social memory for the modern Garifuna ('Black Carib') people of St Vincent and its diasporic communities. The bones of some 2000 men, women and children, ancestors of the modern Garifuna, lie under its stony soil. This is a Caribbean island of profound disquiet and as such presents a contrast to the neighbouring Windward islands. Indeed, in writings about traditional Garifuna ritual and belief, Garifuna ancestors are understood to travel from not only from Sairi (the land of the dead) to visit descendants, but also from Yurumein (St Vincent and Balliceaux) (Johnson, 2018); Yurumein is the Garifuna 
ancestral homeland as it is the physical location of the bones of those who founded their people. The physical and metaphysical dead are bound together here.

As we shall see, Balliceaux, this island of death, is also an important place of memory and place of pilgrimage, an island to be revisited and reintegrated into Garifuna social memory annually. The pilgrimage, a ritual, can be understood in classic rite of passage terms (Van Gennep, 1960). We start with the pre-liminal separation from everyday life in preparation for the journey and boarding the boat - the only means of travel to Balliceaux. Then follows the liminal act of being on the island, kissing the ground, and wailing or keening on arrival, temporarily inhabiting in the betwixt and between space where communion with the land means a visceral connection with the ancestors can take place. Then finally we have the post-liminal journey back-to St Vincent, or 'home' in the diaspora in the knowledge that the continuing bond with the ancestors has been physically embodied. To use a literary trope, Balliceaux thus has a complex biography embracing death, memory and life affirmation.

We take as a starting point for this paper the contention that islands have a distinctive 'biography', or sense of place. Caribbean islands, for example, are today popularly viewed through the prism of Euro-American high-end tourism as places embodying luxurious and sensuous qualities (Nelson, 2011). The reality though is obviously much more complex (Sheller, 2002 passim). We can construct a notional and longer-term biography of the Caribbean islandscape (as seen through European, and Euro-American lenses over the last 500 or so years) with reference to three distinct phases of interaction.

In the very early phase of European contact, from the late- $15^{\text {th }}$ Century, the Caribbean island was perceived as an explorers' idealised botanical and environmental Eden (Grove, 1995; Hulme, 1986), but like its rebellious native inhabitants, it was seen as a place that requiring civilising, taming and making productive (Hollsten, 2008, p. 84). This was achieved in the second phase via the industrialisation of the islandscape in the $18^{\text {th }}$ and early-19 ${ }^{\text {th }}$ Centuries. European and Euro-American notions of industrialised land-use however, required the labour of enslaved Africans to mass produce sugar, and to a lesser extent other cash crops such as indigo, tobacco and cotton. In the final phase, the $21^{\text {st }}$-Century Caribbean island has become a tourist paradise to be enjoyed and 'consumed' by the well-heeled (Gillis, 2010).

Furthermore, each stage of the story (or biography) of the Caribbean islandscape can be seen in terms of a continuum of pre-modernity-modernity-post-modernity, reflecting the transition from the ante/anti-colonial, Calibanesque 'wild island' (Joseph, 1992, p. 1) to (and still using a Caribbean literary analogy) the controlled and externally created Cartesian islandscape of Robinson Crusoe. Crusoe, the archetypal European 'discoverer' of the Caribbean island is: "the perfect Lockean man" who "projects onto the pristine island his desire for power and property" (Peraldo, 2012, p. 19). The Caribbean island thus becomes an exploited, controlled entity both within the context of 'modernist' intensive industrial development through the context of the Plantation economy, and then (and this is often conveniently forgotten) as an equally exploited focus of leisure, an archetypal post-modern transitory place, framed within a subtler and less direct form of economic neo-colonialism. 
The story of the island of Balliceaux, although subject to a different form of historical processes and events to other Caribbean islands, broadly mirrors this tripartite structure: a place of pre-contact settlement, a place of genocide, a place of memory and memorialisation. In order to nuance this biography however, we need to move beyond the external perceptions of the island and engage with the meanings and emotions placed upon it by local communities using an explicitly decolonial approach (Nadarajah \& Grydehøj, 2016). Furthermore, taking our lead from an influential contribution to the discipline of island studies (Hay, 2006), we seek to enrich this biography with reference to metaphors associated with Balliceaux as an island of profound memory, yet also an island of death and grief. In so doing we will argue that this single (and essentially physically unremarkable) island holds up a mirror to (and embodies) the struggles of a small, creolised African-Caribbean population. Using the lens afforded by grief and death studies in general, and in particular by the work on bereavement of the American psychologist Dennis Klass (1991), we build further on this notion of embodiment.

Before considering the historical context that informs the biography of Balliceaux, and the meanings of death, grief and grieving attached to it, let us consider more fully the theoretical underpinning of this paper, and look more closely at the phenomenology of the Caribbean islandscape. As we shall see this is a crucial approach to moving beyond the concept of the physical island to understanding the embodied, metaphysical space in terms of Garifuna emotion, memory and metaphor. This Indigenous-centric methodology offers a fresh perspective to the historiography and study of the Caribbean islandscape (Baldacchino, 2004).

\section{Embodying the Caribbean island biography: Applying phenomenology to islandscapes}

"Phenomenological investigation lays stress upon vernacular construction of meaning and its attendant technologies, beliefs, value codes and myth structures" (Hay, 2006, p. 33)

This quote captures the essence of the phenomenological approach to studying the biography of the Caribbean islandscape (although Hay is writing about islands more generally). To return to the literary allusions presented in the preceding section (and islands do lend themselves to such comparisons; Crane \& Fletcher, 2016), in the case of the insular Caribbean this requires more of an emphasis upon the perspective of Caliban than Crusoe. In broad terms, phenomenology as a philosophical concept focuses upon the study of human perception, sense and experience, and is rooted within the German Romantic movement of the $18^{\text {th }}-19^{\text {th }}$ Centuries (a detailed consideration is beyond the scope of this paper, but useful overviews include Husserl, 2006; Zahavi, 2003).

Our route into the phenomenology of islandscape in the context of this paper is also informed by the work of the British landscape anthropologist and archaeologist, Christopher Tilley (1994). Tilley draws extensively upon theoretical concepts taken from a range of disciplines and is grounded in what is termed a post-processual archaeological position, which de-emphasises the role of functionalism and adaptive 
cultural behaviour, and focuses more upon metaphor, symbolism and embodiment. For Tilley, a landscape is not just a passive palimpsest of physical and historical meanings, it embodies human emotion and sensuality (for wider perspectives and critiques see Ingold, 1993; Johnson, 2012). Furthermore Tilley sees landscapes that are saturated with human memories and feelings, and act as a mnemonic. Taking the work of Hay and Tilley together, we can appreciate the possibilities of an exciting theoretical approach for seeing islands as rich symbolic metaphors and wells of social memory. As Pete Hay states, "Islands are places, special places, paradigmatic places, topographies of meaning in which qualities that construct place are dramatically distilled" (Hay, 2006, p. 31). As we shall see, as an islandscape Balliceaux dramatically distills a range of human emotion, but as previously noted, little of it is positive.

Hay's paper, while providing us with a broad phenomenological approach to exploring Balliceaux, also identifies three concepts (or 'fault-lines') that require our attention. Firstly, the notion of islands having a hard edge or boundary is disabused; they inspire transgression and movement, and as permeable and connected entities, islands cannot be viewed in isolation. His second fault-line relates to this permeability through human immigration and emigration, both provoked in differing ways as a response to economic stimuli. His third fault-line focuses upon the island as a metaphor (Baldacchino, 2012; Gillis, 2004 passim), a concept closely related to the archaeological approach articulated by Tilley above. It is this third fault-line that most interests us most here as any 'meaning' of an island as a place, is fluid and responsive to historical and political contingency (Escobar, 2001; Harvey, 1996).

The writings of the Martinique-born Francophone author Édouard Glissant (1928-2011) inter alia show how Hay's ideas (and to some extent those of Tilley) can be applied within a Caribbean insular context. In his 1958 work La Lézard (The Ripening), Glissant views his home island of Martinique in explicitly feminine terms, and the whole island is structured through symbolic geographical and environmental reference points; mountains, plants and places (Heller, 1996). In his Discours Antillais (Caribbean Discourse), Glissant (1992, p. 63) that the imposition of the European plantation system on these islands, as a manifestation of capitalism and modernity, suppressed a 'natural/cultural dialectic', and he therefore urges Afro-Caribbeans to 'reterritorialise' (re-naturalise) the Caribbean island, which for him is also a historical monument, a place of memory (Deloughery, 2001, p. 34). Archaeology and anthropology can also assist in theorising the notion of the Caribbean island landscape embodying resistant strategies, using nature and the local to overcome the imposed colonial systems of control and surveillance (Delle, 1999).

The work of American anthropologist Lydia Pulsipher (along with her local collaborators) in Montserrat comes close to viewing from the 'bottom up' by focussing on enslaved peoples' perceptions of their landscapes and environments through the study of small-scale hidden slave gardens as a mechanism for economic independence and resistance (Pulsipher \& Goodwin, 2001), and this local knowledge persists to this day. On Barbados, runaway slaves were often drawn to caves in the interior of the island as a means of finding their 'own' social space, places of refuge to reconnect with their African ancestral deities through deposition of iron artefacts (Armstrong, 2015). Meanwhile, the work of American archaeologist Matthew Reilly (2019) among the 
'poor white' communities of the eastern side of Barbados 'below the cliff has started to reveal the symbolic attachment to a very circumscribed area of the island by a marginalised and largely ignored community; poor whites were imported into Barbados as a form of indentured labour during the $17^{\text {th }}$ Century and as such should not be understood as part of the ruling Plantocracy.

Balliceaux is also a metaphor for resistance embodied in a Caribbean island landscape, albeit in a more nuanced manner. Balliceaux, as we shall see, is a place of grief and memory. It is also place of exile, but also paradoxically a place of return through pilgrimage and a place held up as a memory of the struggle against colonialism, but also for reparations against its horrors. In order to understand these multiple meanings, we need to consider Balliceaux's historical context in more detail.

\section{Balliceaux: A historical biography of a small Caribbean islandscape}

The Garifuna, or 'Black Caribs', developed as a separate and distinctive island population on St Vincent at some point in the late- $17^{\text {th }}$ Century, their ethnogenesis being the result of intermingling between Indigenous 'Island' (otherwise known as 'yellow/red') Caribs and shipwrecked enslaved Africans, or runaway slaves from neighbouring islands such as Barbados. The British anthropologist, the late Charles Gullick, remains the author of the key work on the Vincentian Garifuna, and he provides a succinct and balanced overview of their origins myths as he heard them during his fieldwork in the 1970s (Gullick, 1985, p. $39 \mathrm{ff}$; space precludes an overview of the issue of the historical, archaeological and anthropological validity of the term 'Carib'; see Allaire, 2013 for an overview of current debates).

It is during the late- $18^{\text {th }}$ Century that the Garifuna/Black Caribs become more visible as a distinctively cultural creolised group. This was a period when the French and British were vying for control of the south-eastern Caribbean; the Caribs (both 'yellow/red' and 'Black') had been ceded their own ancestral lands in the north of the island of St Vincent, which they referred to as Yurumein. These agreements were however, broken by the British (Kirby \& Martin, 2004). Guerrilla war broke out between the Black Caribs and the British in 1769-1773 and then 1795-1796, in what became known as the Black Carib Wars (see Taylor, 2012 for the definitive account). Finally, in 1796 the Black Caribs, under their leader Paramount Chief Joseph Chatoyer, were defeated by the British and had harsh terms imposed on them. In order to 'solve' the Black Carib problem, the British decided that they should be removed from St Vincent.

It is estimated that some 4195 Caribs (mostly Black but also some Yellow/Red Caribs) were forcibly removed to Balliceaux in October 1796 (Gonzalez, 1988, p. 35), an island with minimal facilities and no access to fresh water; some reports suggest however, that there were as many as 5080 exiles (Bullen \& Bullen, 1972, p. 40). Although provided with canoes and fishing tackle, as well as the services of a doctor when required, and regularly provisioned with water and food (Anderson, 1992 [c1798], p. 227), approximately 2000 Carib men, women and children died there, mainly through disease (Taylor, 2012, p. 163). The surviving Yellow/Red Caribs were returned to St Vincent (Gonzalez, 1988, p. 35), while the Black Carib survivors were boarded onto 
HMS Experiment on 3 March 1797, and five weeks later on 12 April "were dumped on the island of Roatán off the coast of Honduras" (Anderson, 1997, p. 27).

Balliceaux as an islandscape thus has a very troubled history, and to date no archaeological work has taken place on the island with the express intention of locating human remains or land-use dating from this dark episode. But it would be incorrect to assume the Garifuna exile is its only history. In 1969, the American archaeologists Ripley and Adelaide Bullen visited the island, and whilst locating some 'Peasant Ware' they believe may be related to the 1797 exile, only found evidence of extensive habitation dating to the Suazey/Suazoid period, i.e. 1000-1500 CE (Bullen \& Bullen, 1972, p. 36; see also Fewkes, 1922). In more recent times a plantation briefly existed there, and today the island remains in private ownership, and is essentially scrubland.

The descendants of those forcibly exiled to Balliceaux continue to live in Central America (e.g. Belize, Honduras) and have more recently established themselves in North American cities such as Los Angeles and New York (Johnson, 2007). The terms ethnic cleansing and cultural genocide do not fall too short by way of descriptions for this 1797 expulsion, and this is how the episode is widely perceived. Indeed, the deportation of most of the Garifuna (a small number managed to evade capture and remained on St Vincent in hiding; see Pollard, 2014, p. 133) and their safe landing in Central America is still recalled today in annual commemorations. 12 April is the Punta Gorda Festival in Roatán, which celebrates the welcoming of the exiled onto the island, and 19 November is Settlement Day in Belize which celebrates the arrival of the 'Garinagu' (their term for Garifuna) in that country. In St Vincent, the exile is annually remembered on National Heroes Day (14 March). Chatoyer is the country's first (and currently only) National Hero, and the deportation often features in political discourse; a particular favoured topic of St Vincent's left-wing Prime Minister Ralph Gonsalves, himself author of the Caricom reparations for slavery policy.

For the Garifuna generally but especially those in the diaspora communities, Balliceaux has, by and large, become a byword for their diasporic exile, the attempted destruction of their Black Carib identity, and death in what is often described as a 'concentration camp' setting (Hulme, 1991, p. 193; Palacio, 2002; Alvarez, 2008, p. 32, Tate \& Law, 2015, p. 20). The history of Garifuna, and their exile has placed St Vincent as the motherland of this ethnic and cultural group, it is Yurumein, their birthplace and spiritual home (Johnson, 2007, p. 180). Further, it has framed Balliceaux as a, if not the, Garifuna place of pilgrimage and memory. Thus, we can see an implicit linkage here of three geographically separated islands that make sense as an 'emotional' rather than 'physical' archipelago (Pugh, 2013): St Vincent, the Garifuna homeland; Ballicea,ux the place of brief exile and suffering; Roatán, the place of secondary exile and freedom. During our ethnographic work we have interviewed a range of Garifuna people, and the one overriding emotion that is emphasised when talking about their psychological archipelago, is that Balliceaux is the most important of these islands, and alone is associated with loss, grief and grieving.

The biography of Balliceaux's islandscape as a setting of exile and death has, as previously noted, the further attribute of being additionally a place of pilgrimage by the descendants of those who settled in Roatán and moved outwards to other diasporic locations. As such Balliceaux is a very meaningful Caribbean island for the Garifuna, 
especially those in diaspora. But the island has meaning to non-Garifuna others, as more pragmatic 'values' are attached to the place. Since the $19^{\text {th }}$ Century the island has been in the private ownership of one family, the Lindleys, and of late many rumours have circulated within St Vincent and among the Garifuna diaspora that the island would be sold for development as a luxury holiday resort. Predictably such news has caused widespread disquiet among local and diaspora Garifuna peoples (privateislandsonline.com, 2019).

The proceedings of the Fifth International Garifuna Conference in Kingstown, St Vincent and the Grenadines in March 2018 were given over to strategies on how to save Balliceaux. Calls for Gonsalves' Government to meet the alleged US $\$ 30$ million asking price to buy the island for the nation were rebuffed by politicians (according to the latest figures, the country's annual GDP is approximately US\$800 million; Vanessa Demirciyan, personal communication, 2018). At the time of writing these rumours remain just rumours, but the picture is uncertain. However the situation resolves itself, there is a realisation that this is more than a physical island, it is an embodiment of a peoples' communal memory and sense of grief. Taking, then, this phenomenological approach outlined above, we can begin to perceive deeper meanings of the island of Balliceaux, based upon a site of memory generally, and a site of grief and grieving more specifically.

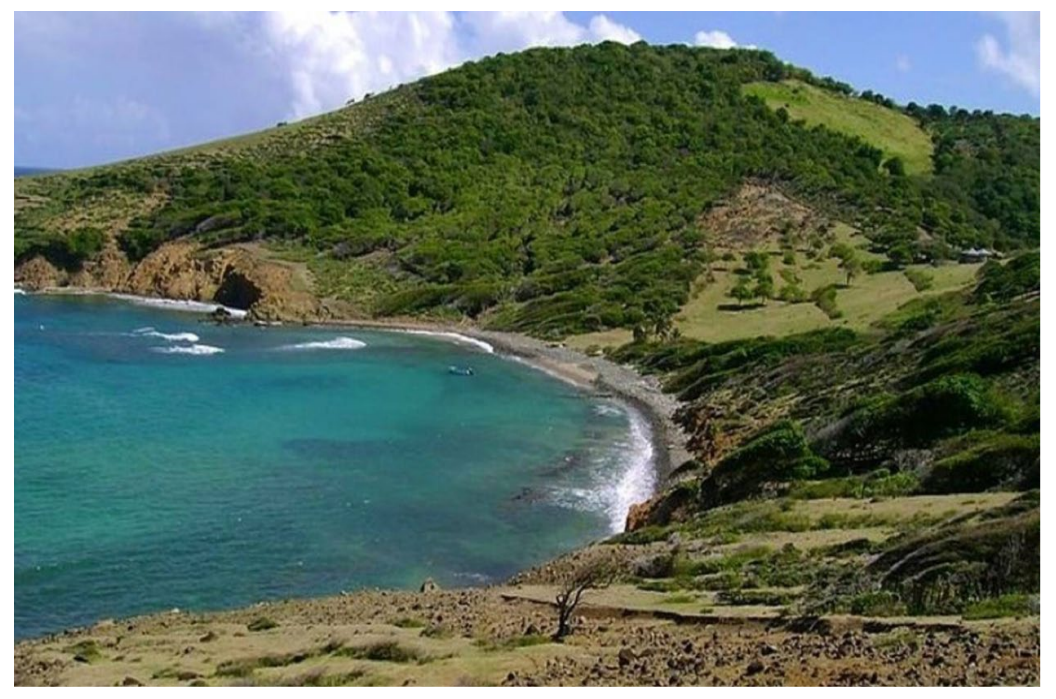

Figure 2. View over the west coast of Balliceaux showing the island landscape. (C) Niall Finneran \& Christina Welch

\section{Balliceaux as a site of memory}

The meaningfulness of Balliceaux for the Garifuna lies beyond the island's history as a site of temporary settlement between their exile from St Vincent and their transportation to Roatán, for a noted earlier, the site was not just a transitory home. The death of approximately 2000 Garifuna on Balliceaux means that the island is the permanent home to the bones of those who died there, and the continuing presence of the dead is felt by Garifuna pilgrims who travel to the site to connect with Yurumein and their ancestors (Leland \& Berger, 1998). The island also has mythic significance 
through the ancestors on Balliceaux in traditional healing rituals known as Dügü (Jenkins, 1983; Flores, 2002; Johnson, 2018).

A place of memory is a site that resonates with where one locates one's sense of "self and being," it is a location of memory and of mythic history (Nora, 1989). It is also a place where typically those who are "outsiders to the place" are considered by its inhabitants, or here the descendants of its inhabitants, to be incapable of recognising "the territory's sacred qualities" (Olúpònà, 2011, p. 24); hence the disquiet concerning the possible sale of the island by its owners. Sites of memory typically have a mythic history (mythscape; Bell, 2003; Rojas, 2013), and with myth crucial to identity and often the bedrock to ritual, sense of place sites potently enforce and reinforce community.

In terms of the island of Balliceaux, this mythic history, and the rituals that take place during the pilgrimages to the island and during Dügü, centre on the suffering of exiled ancestors and on the site as an effective cemetery for those who perished there. This perception was powerfully expressed by Michael Polonio, President of the Belizean National Garifuna Council, in a letter sent to the Prime Minister of St Vincent and the Grenadines in 2005. It stated that the island is "the burial ground of our ancestors," their resting place and the home to "the souls of our ancestral dead" (qtd. in Middleton, 2014, p. 31). This assertion was reiterated by David 'Darkie' Williams, President of the St Vincent and the Grenadines Garifuna Heritage Foundation in his opening address to the $5^{\text {th }}$ International Garifuna Conference on 12 March 2018, which emphasised the island's sacred qualities as a place of memory to all Garifuna.

We have noted above that Balliceaux is a metaphor for (and embodiment of) Garifuna grief yet also a place where memory is continually being refreshed through pilgrimage. The island reflects Garifuna recent history, and taking this explicitly phenomenological approach, Balliceaux becomes more than a physical island that has monetary or aesthetic value. As a place of memory it has considerable potency. Now we propose to investigate this idea using a perspective drawn from the field of grief and death studies to help us think through the process of how the Garifuna engage with the island as a place of mourning. We will be using the work of the psychologist Dennis Klass (2001) to consider the mechanisms by which societies and individuals grieve, and how this action can give meaning to a physical island.

\section{Mourning Balliceaux}

As a number of scholars have noted, because one's identity is powerfully linked with place and memory, to home and history, when dislocation occurs (such as forced resettlement from one island to another), grief typically follows (Pflüg, 1998; Volkan, 2017). Grief theory and the study of death is a relatively new academic field, although one largely concerned with the changing patterns of death and grief-related behaviour in the industrial West and Westernised world (Klass, Silverman, \& Nickman, 1996; Garces-Foley, 2006; Davies \& Park, 2012). Explorations of rituals per se and ceremonial practices outside the West and the main 'World Religions', have typically been the preserve of anthropologists, ethnographers, and more recently scholars of religion, but increasingly, death studies scholars and psychologists have engaged with non-Western lifeways and deathways to explore cultural expressions of grief (e.g. Ebenstein, 2017: 
Jonsson \& Walter, 2017). Although a very recent addition to the death studies field, Jonsson and Walter (2017, p. 408) have briefly touched on peoples' continuing bonds with land through applying grief studies to the notion of the phenomenology of place. They suggest that "thinking about ancestors has potential to illuminate the special location of continuing bonds." This is a useful approach to considering the attachment of the Garifuna to this special island.

In 2001 the American psychologist Dennis Klass published an article that suggested that death and grief are understood in a social/society rather than individual/familial context. Klass (2001) argued that in Japan, for example, while mourning rituals are changing to fit in with the contemporary high-tech world (for instance see Martin, 2017), they retain traditional elements including the notion that the uncared-for death can bring potential harm and/or dis-ease to not only relatives of the deceased, but also to Japan as a nation. The perception that the uncared-for dead can bring about problems for a community is not untypical in many religions, especially those with an African origin such as the Garifuna (Jindra \& Noret, 2011; Alolo \& Connell, 2013; Ekore \& Lanre-Abass, 2016). The Garifuna human remains on Balliceaux, although not visible or discovered, pervade the islandscape and have to be mourned in the correct way.

Although in a different context from the Garifuna's ancestral grief and their connections to Balliceaux as the home to the bones of their exiled ancestors, Klass' studies into the affect of grieving, have relevance. In trying to understand approaches to dealing with grief, he explored parental grief from infant death in America, and noted four cross-cultural ways that the parents interacted with their deceased child (Klass, 2001, p. 752). We suggest that these ideas are applicable to the continuing bonds that the Garifuna have with Balliceaux. Let us consider each of Klass' "paths to solace" in order, relating them to how the Garifuna encounter their special island of memory.

Klass' (2001, p. 752) first path to solace is 'linking objects'. These are physical objects that in his study were understood by grieving parents as containing the presence of the deceased child. As Jonsson and Walters (2017, p. 409) argue in their paper on continuing bonds and place, a location can become a linking object providing a deep connection to the dead, recent and/or ancestral. Thus we argue, Balliceaux acts as a 'linking object' for the contemporary Garifuna, providing a tangible connection with their ancestors who died there. It also affords them a sense of solace, because not only are their ancestors 'at rest' on the island, but through pilgrimages to the island, the linking bond with them is retained across the generations (England, 1999).

The Garifuna connection with their ancestors resonates potently with the findings of a study by Laurie and Neimeyer (2008, pp. 176-177) into the experiences of grief amongst African-Americans in America. They noted that "experiences of an ongoing spiritual connection with the deceased" amongst the descendants of enslaved Africans was stronger than that of Euro-Americans, and that ritual and mythic interconnectedness, strengthen a sense of self-identity in those with a past where dislocation due to the slave trade was strong. Further evidence that Balliceaux can be understood as a potent linking object for the Garifuna comes from Tutter's (2016, p. xxxviii) exploration into the ways that grief is traditionally transcended. She argues that for displaced people in particular "the periodic traveling of ancestral paths" helps secure 
links between the past and future. The connections between memory, and identity need, she argues, to be assured in order to provide some consoling sameness against the devastation of loss.

Klass's (2001, p. 753) second path to solace he terms 'religious ideas and devotion'. Here Klass found that the use of prayers and rituals provided the bereaved parents with meaning, often allowing them to sense the presence of their child, and their deity. Most Garifuna today are Christian or combine Christianity (in many different forms) with traditional beliefs (Norales, 2011), and whilst the complexity of Garifuna religious expression is beyond the scope of this paper, rituals that involve ancestors are central to traditional Garifuna culture (Foster, 1987; Kerns, 1997). Regardless of which religion the Garifuna use to commune with their ancestors, communication does take place, and ritual pilgrimages to Balliceaux strengthen ancestral connections.

Further, given the deeply traumatic experience that the dislocation of the Garifuna from their homeland would have brought about, alongside the death of several thousand of them on Balliceaux, as Gump (2010, p. 46) argues in the context of African enslavement in America, ancestral traumas require a form of revisiting to provide meaning, or "solace and release." Here the findings of Tutter, Gump and Laurie and Neimeyer combine, we maintain, to position Balliceaux as the place of Garifuna memory, as the space where connections to the exiled ancestors allow the fortification of Garifuna-ness as an identity. The island thus inspires and incites expressions of grief, grief centred around not just exile, loss, and death (Leland \& Berger, 1998), but also survivance-meaning a cultural continuation that is greater than survival (Vizenor, 1998, p. 15; Vizenor, 2008).

The third of Klass' (2001, p. 753) four paths to solace is 'memory'. Remembering the deceased is important for the bereaved but in Klass' study it refers to memory related to the grieving parents remembering better and happier times. We do not wish to suggest that times for the Garifuna were better on Balliceaux, as it marks the end of their time on Yurumein and their defeat at the hands of the British, but the island has a potent mythscape. It functions as a location for the on-going expression of grief regarding the loss of the Garifuna's 'golden age' (Foster, 1987, p. 77), and the historical events leading up to the exile and the diaspora that followed. Balliceaux therefore holds a potent place in the memory of the Garifuna people, and as noted, is central to their self-identification, and 'Identification', is the last of Klass' (2001, p. 753) paths to solace.

For Klass, identification relates to storying. For the bereaved parents in his study, identification involved making an inner representation of the deceased child part of their own self-representation, and indeed incorporating the deceased into one's own ongoing story is normative (Klass, Silverman, \& Nickman, 1996; Pector, 2002; Field, Gao, \& Paderna, 2005). For the Garifuna, the ancestors on Balliceaux, and the life they led before exile from Yurumein are fundamental to their story. The dead are not forgotten but return in traditional Dügü ritual (Jenkins, 1983; Flores, 2002; Johnson, 2018), and are central to the Balliceaux pilgrimage; they are an important part of being Garifuna, particularly for those in the diaspora.

The Garifuna identification with their ancestors relates to findings from Klass' follow-up 2017 study, which explored sustained interactions with the dead, and the 
continuation of bonds with them. Klass in his study on continuing bonds with the deceased, noted that the deceased frequently became role models for his interviewees. He found that his subjects would often draw on the wisdom and strength of deceased close relatives and friends; typically, their guidance was sought in specific situations, often where the bereaved would have sought support from the deceased person were they alive (Klass \& Steffen, 2017, p. 147). In Garifuna culture, ancestors similarly provide strength and wisdom to contemporary Garifuna people, and in Dügü rituals they are called upon for specific healing purposes (Jenkins, 1983; Kerns, 1997; Greene, 1998; Flores, 2002; P. Johnson, 2002; C. Johnson, 2018). The bonds that the Garifuna have between the living and the dead continue over generations and span the centuries, and thus conform to the first two of Klass' (2017, p. 147) four 'functions of the dead'; they act as a 'Role Model' (strength and wisdom), and provide 'Situation-Specific Guidance' (through Dügü).

The courage and endurance of those exiled to Balliceaux can be understood to echo Klass' (2017, p. 147) third function of the dead, which is 'values clarification'. According to Klass, the bereaved he interviewed would take up a moral position that they believed conformed to that of the deceased. In terms of the ancestors who died on Balliceaux, the autonomy of their life on Yurumein, their fortitude and tenacity in the face of colonialism, are aspects that are commemorated, and celebrated; they are central to Garifuna identity and the freedom-fighter rhetoric is often repeat in St Vincent and the Grenadines through the figure of Chatoyer, and in diaspora via the annual commemorations which foreground pride in Garifuna heritage.

Klass' final function of the dead, 'remembrance formation', echoes the Garifuna strength in their past. For Klass' (2017, p. 148) interviewees, they spoke of remembering the deceased in ways that made them feel better, that gave them solace, and this can be seen in multiple Garifuna narratives. In the film, The Garifuna Journey, tradition bearer, Roy Cayetano states that he admires "the versatility of [the] ancestors who were deported from St. Vincent." He notes that they provide "strength" to the Garifuna today, and that the mutual obligations with the recent and ancestral dead "cut across the borders of this life" (qtd. in Leland \& Berger, 1998). For the Garifuna then, Balliceaux is not just a place of pilgrimage, but it is a potent site of memory; it is a site that is central to their self-identification and their pride as a people. It is both a place of solace and fulfils Klass' functions of the dead.

In a 2017 study on the topic of continuing bonds, death studies scholars Annika Jonsson and Tony Walters explore the importance of place to bereaved people. Drawing on the phenomenology of place attachment, they found that cross-culturally, there was a potent connection between place and memory, and that their interviewees told them about places "in which continuing bonds with the deceased [were] particularly vivid" (Jonsson \& Walters, 2017, p. 413). They further noted, that the destruction of somewhere significant to the bereaved in terms of their relationship to the deceased (such as the deceased's former home, or other potent memory places) had a disruptive effect on the bereaved's connection with the deceased. Their participants, regardless of age or geographical location (provided their pre-death relationship was positive), found that the enforced break in connection was often unsettling as the placespecific interaction helped "anchor continuing bonds" (Jonsson \& Walters, 2017, p. 
411). Although the Jonsson and Waters study highlights the importance of place to those who had a living memory of the familial deceased, as with Klass' studies, they emphasise the potency of connections with the dead. For the Garifuna, the longdeceased ancestors on Balliceaux and in the form of National Hero Chatoyer (a symbol of the Garifuna who perished fighting the British to retain their homeland), are vital symbols of identity, of minority resistance, and of survivance. Balliceaux as a specific place anchors this connection and its importance in Garifuna history and memory is not one to be underestimated.

\section{Conclusion}

"Balliceaux has escaped the commercialization and development that many of its Windward Island neighbors have succumbed to, making this [...] paradise one of the last truly unspoiled gems in the Lesser Antilles [...] this magnificent isle is an undeveloped gem just waiting for the right person to let it shine."

Sales advertisement,

https://www.privateislandsonline.com/islands/balliceaux-island

The foregoing analysis has shown how, using a predominantly phenomenological approach foregrounded the work of Tilley and Hay, and using a framework of analysis drawn from scholarship in grief and death studies, we can start to take an embodied approach to a Caribbean islandscape, albeit one with a distinctive and complex history. Balliceaux is more than just 'an island'; it embraces many differing values. There is the financial and personal value held by its current owners, the Lindley family, with its potential as a luxury high-end tourist resort (as the quote at the top of this section demonstrates). To the St Vincent Government it is a politically loaded potential heritage site that they would rather not engage with. To researchers from the outside, it represents an important historical site, a place of genocide, and perhaps a prototype of later British models for concentration camps.

It is not difficult to position Balliceaux as part of a wider continuum of the island as place of isolation, death and exile throughout human history. Islands have, since the earliest days, traditionally been used as places of detention, exile ( $f$. Tolias, 2013) and imprisonment (Mountz, 2017; Vannini, 2011): Alcatraz, Ellis Island, Robben Island, Devil's Island, Nauru, etc. have understandably taken on qualities as potent places of memory and commemoration (Luo \& Grydehøj, 2017). For the Garifuna though, as we have demonstrated, and taking a broader theoretical perspective drawn from grief and death studies, we can see it being more than just a place of pilgrimage, or a sacred island, but a place where the ancestors dwelt, and a cipher for Garifuna identity and a place of memory.

To return to Hay's three fault-lines in the phenomenology of island settings, we have established the third, the notion of metaphor, but what of the other two? Balliceaux does inspire transgression as its boundaries are not impermeable at all. The act of Garifuna pilgrimage shows how the island's boundaries are crossed. Further, as we look at Hays' second fault-line we realise that rather looking at a 'normal' 
emigration/immigration situation, we have here forced emigration over 200 years ago, and the 'new' immigrants are the Garifuna pilgrims, returning as part of a mourning ritual.

We have taken a decolonial approach (Grydehøj, 2017) to the Caribbean islandscape represented here by Balliceaux; echoing we hope the stance of Caliban rather than Crusoe. This approach offers a new way of thinking through the Caribbean island away from the top down and Cartesian lens of colonial history books, where Balliceaux is reduced to just a small and marginal $\operatorname{cog}$ in a wider imperial system of coercion and control, and away from the language of the real estate agent or tour company that speaks of hidden gems and tropical paradises.

The biography of Balliceaux revealed here speaks directly to Hays' urge to reach into vernacular constructions of meaning rather than metanarratives constructed externally. And to return too to Johnson's third comment about the phenomenological approach, it raises the question of the politicisation of the islandscape, which within the wider context of Indigenous rights in the Caribbean is a very real and insistent issue and one that highlights the value of a decolonial approach to island studies on a wider scale (Nadarajah \& Grydehøj, 2016).

\section{Acknowledgements}

We wish to thank the following individuals who have supported so generously our research in St Vincent: Zoila Ellis, David 'Darkie' Williams, Vanessa Demirciyan and Nicola Redway. We also thank Jonathan Pugh for his editorial patience and for seeing the merit in the paper, and the input of two anonymous reviewers whose suggestions resulted in a much more effective end result. Funding for the fieldwork was provided by the University of Winchester.

\section{References}

Allaire, L. (2013). The ethnohistory of the Caribs. In W.F. Keegan, C.L. Hofman, \& R.R. Rodriguez (Eds.), The Oxford handbook of Caribbean archaeology Ramos (pp. 97-110). Oxford University Press. https://doi.org/10.1093/oxfordhb/9780195392302.001.0001

Alolo, N.A., \& Connell, J.A. (2013). Indigenous religions and development: African traditional religions. In M. Clarke, (Ed.). Handbook of research on development and religion (pp. 138-164). Edward Elgar. https://doi.org/10.4337/9780857933577.00015

Alvarez, S.J.R. (2008). Preservation strategies of the Garifuna language in the context of the global economy in the village of Corozal in Honduras. DPhil thesis, University of Florida.

Anderson, A. (1992 [c. 1798]). Alexander Anderson and the Carib War in St Vincent (1798). In P. Hulme \& N.L. Whitehead (Eds.), Wild majesty: encounters with Caribs from Columbus to the present day (pp. 216-229). Oxford University Press.

Anderson, M. (1997). The significance of blackness: Representations of Garifuna in St. Vincent and Central America, 1700-1900. Transforming Anthropology 6(1-2), 22-35. https://doi.org/10.1525/tran.1997.6.1-2.22

Armstrong, D.V. (2015). Cave of iron and resistance: A preliminary examination. Journal of the Barbados Historical Society, 61, 178-199. 
Baldacchino, G. (2004). The coming of age of island studies. Tijdshrift voor Economische en Social Geografie, 95(3), 272-283. https://doi.org/10.1111/j.1467-9663.2004.00307.x

Baldacchino, G. (2012). The lure of the island: A spatial analysis of power relations. Journal of Marine and Island Cultures, 1(2), 55-62. https://doi.org/10.1016/j.imic.2012.11.003

Bell, D.S.A. (2003). Mythscapes: Myth, memory, and national identity. British Journal of Sociology, 54(1), 63-81. https://doi.org/10.1080/0007131032000045905

Bullen, R.B., \& Bullen, A.K. (1972). Archaeological investigations on St. Vincentișepiand the Grenadines, West Indies. William Bryant Foundation, American Studies, Report No. 8.

Crane, R., \& Fletcher, L. (2016). The genre of islands: Popular fictions and performative geographies. Island Studies Journal, 11(2), 637-650.

Davies, D.J., \& Park, C-W. (Eds.) (2012). Emotion, identity and death: Mortality across disciplines. Ashgate.

Delle, J.A. (1999). The landscapes of class negotiation on coffee plantations in the Blue Mountains of Jamaica: 1790-1850. Historical Archaeology, 33(1), 136-158. https://doi.org/10.1007/bf03374284

Deloughery, E.M. (2001). "The litany of islands, the rosary of archipelagos": Caribbean and Pacific archipelagraphy. ARIEL, 32(1), 21-51.

Ebenstein, J. (2017). Death: A graveside companion. Thames and Hudson.

Ekore, R.I., \& Lanre-Abass, B. (2016). African cultural concept of death and the idea of advance care directives. Indian Journal of Palliative Care, 22(4), 369-372. https://doi.org/10.4103/0973-1075.191741

England, S. (1999). Negotiating race and place in the Garifuna diaspora: Identity formation and transnational grassroots politics in New York City and Honduras. Identities, 6(1), 553. https://doi.org/10.1080/1070289x.1999.9962635

Escobar, A. (2001). Culture sits in places: Reflections on globalisation and subaltern strategies of localisation. Political Geography, 20(2), 139-174. https://doi.org/10.1016/s0962$\underline{6298(00) 00064-0}$

Fewkes, J. W. (1922). A prehistoric island culture of America: Thirty-fourth annual report of the Bureau of American Ethnology, 35-281.

Field, N.P., Gao, B., \& L. Paderna, L. (2005). Continuing bonds in bereavement: An attachment theory based perspective. Death Studies, 29(4), 277-299. https://doi.org/10.1080/07481180590923689

Flores, B. (2002). The Garifuna Dügü ritual in Belize: A celebration of relationships. In R.R. Ruether (Ed.), Gender, ethnicity and religion (pp. 144-170). Fortress.

Foster, B. (1987). Celebrating autonomy: The development of Garifuna ritual on St Vincent. Journal of Caribbean Culture, $33 \quad$ (3-4), 75-83. https://doi.org/10.1080/00086495.1987.11671718

Garces-Foley, K. (Ed.) (2006). Death and religion in a changing world. Routledge.

Gillis, J.R. (2004). Islands of the mind: How human imagination created the Atlantic World. Palgrave Macmillan.

Gillis, J.R. (2010). Island sojourns. Geographical Review, 97(2), 274-287. https://doi.org/10.1111/j.1931-0846.2007.tb00403.x

Glissant, E. (1992) Caribbean discourse: Selected essays. M. Dash (Trans.) Caraf Books \& University of Virginia. 
Gonzalez, N.L. (1988). Sojourners of the Caribbean: Ethnogenesis and ethnohistory of the Garifuna. University of Illinois Press.

Greene, O.N. (1998). The 'Dügü' ritual of the Garinagu of Belize: Reinforcing values of society through music and spirit possession. Black Music Research Journal, 18(1-2), 167181. https://doi.org/10.2307/779397

Grove, R.H. (1995). Green imperialism: Colonial expansion, tropical island edens and the origins of environmentalism 1600-1860. Cambridge University Press. https://doi.org/10.1017/s0021853796466907

Grydehøj, A. (2017). A future of island studies. Island Studies Journal, 12(1), 3-16. https://doi.org/10.24043/isj.1

Gullick, C.J.M.R. (1985). Myths of a minority. Van Assen.

Gump, J. (2010). Reality matters: The shadow of trauma in African-American subjectivity. American Psychological Association, 27(1), 42-54. https://doi.org/10.1037/a0018639

Harvey, D.J. (1996). Justice, nature and the geography of distance. Blackwell.

Hay, P. (2006). A Phenomenology of islands. Island Studies Journal, 1(1), 19-42.

Heller, B.A. (1996). Landscape, femininity and Caribbean discourse. MLN, 111(2), 391-416. https://doi.org/10.1353/mln.1996.0024

Hollsten, L. (2008.) Controlling nature and transforming landscapes in the early modern Caribbean. Global Environment, 1, 80-113. https://doi.org/10.3197/ge.2008.010104

Hulme, P. (1986). Colonial encounters: Europe and the native Caribbean. Methuen.

Hulme, P. (1991). Rewriting the Caribbean past: Cultural history in the colonial context. In J.H. Pittock \& A. Wear (Eds.), Interpretation and cultural history, (pp. 175-198). Macmillan. https://doi.org/10.1007/978-1-349-21272-9 8

Husserl, E. (2006). The basic problems of phenomenology. Springer.

Ingold, T. (1993). Temporality of landscape. World Archaeology, 25, 152-174. https://doi.org/10.1080/00438243.1993.9980235

Jindra, M., \& Noret, J. (2011). African funerals and socio-cultural change: Review of momentous transformations across a continent. In N. Jindra \& J. Noret (Eds.), Funerals in Africa: Explorations of a social phenomenon (pp. 16-40). Berghahn. https://doi.org/10.5771/0257-9774-2013-1-329

Jenkins, C.L. (1983). Ritual and resource flow: The Garifuna 'Dügü'. American Ethnologist, 10(3), 429-442. https://doi.org/10.1525/ae.1983.10.3.02a00020

Jonsson, A., \& Walters, T. (2017). Continuing bonds and place. Death Studies, 41(7), 406415. https://doi.org/10.1080/07481187.2017.1286412

Johnson, C. (2018). “The dead don't come back like the migrant comes back": Many returns in the Garifuna Dügü. In M. Forde \& Y. Hume (Eds.), Passages and afterworlds: Anthropological perspectives on death and mortuary rituals in the Caribbean (pp. 31-53). Duke University Press. https://doi.org/10.1215/9781478002130-003

Johnson, M. (2012). Phenomenological approaches in landscape archaeology. Annual Review of Anthropology, 41, 269-284. https://doi.org/10.1146/annurev-anthro-092611-145840

Johnson, P.C. (2002). Migrating bodies, circulating signs: Brazilian Candomblè, the Garifuna of the Caribbean, and the category of indigenous religions. History of Religions, 41(4), 301-327. https://doi.org/10.1086/463690 
Johnson, P.C. (2007). On leaving and joining African-ness through religion: The 'Black Caribs' across multiple diasporic horizons. Journal of Religion in Africa, 37, 174-211. https://doi.org/10.1163/157006607x188911

Joseph, M.P. (1992). Caliban in exile: The outsider in Caribbean fiction. Greenwood Press.

Kerns, V. (1997). Women and the ancestors: Black Carib kinship and ritual. University of Illinois Press.

Kirby, I.E., \& Martin, C.I. (2004). The rise and fall of the Black Caribs (Garifuna). Cybercom.

Klass, D. (2001). Continuing bonds in the resolution of grief in Japan and North America. $\begin{array}{llll}\text { American } & \text { Behavioral } & \text { Scientist, } & 44(5),\end{array}$ https://doi.org/10.1177/00027640121956476

Klass, D., Silverman, P.R., \& Nickman, S.L. (Eds.) (1996), Continuing bonds: New understandings of grief. Routledge.

Klass, D., \& Steffen, E. (2017). Continuing bonds in bereavement: New directions for research and practice. Routledge. https://doi.org/10.4324/9781315202396

Leland, A., \& Berger, C. (1998). The Garifuna journey. New Day Films.

Laurie, A., \& Neimeyer, R.A. (2008). African Americans in bereavement: Grief as a function of ethnicity. Omega, 57(2), 173-193. https://doi.org/10.2190/OM.57.2.d

Luo, B., \& Grydehøj, A. (2017). Sacred islands and island symbolism in ancient and imperial China: An exercise in decolonial island studies. Island Studies Journal, 12(2), 25-44. https://doi.org/10.24043/isj.19

Martin, A. (2017, July 5). Modern mourning at Japan's high-tech cemeteries. Nikkei Asian Review. Retrieved from https://asia.nikkei.com/Life-Arts/Life/Modern-mourning-atJapan-s-high-tech-cemeteries2

Middleton, B. (2014). A landscape of cultural patrimony: Opportunities for using private conservation tools to protect Balliceaux. Caribbean Quarterly, 60(2), 29-52. https://doi.org/10.1080/00086495.2014.11671887

Mountz, A. (2017). Island detention: Affective eruption as trauma's disruption. Emotion, Space and Society, 24, 74-82. https://doi.org/10.1016/j.emospa.2017.02.006

Nadarajah, Y., \& Grydehøj, A. (2016). Island studies as a decolonial Project. Island Studies Journal, 11(2), 437-446.

Nelson, V. (2011). The landscape reputation: Tourism and identity in the Caribbean. Tijdshrift voor Economische en Social Geografie, 102(2), 176-187. https://doi.org/10.1111/j.14679663.2010.00608.x

Nora, P. (1989). Between memory and history: Les lieux de mémoire. Representations, 7-24. https://doi.org/10.2307/2928520

Norales, F.O. (2011). Communicating the Garifuna culture in contemporary church music. The Journal of Aesthetic Education, 45(1), 74-88. https://doi.org/10.1353/jae.2011.0000

Olúpònà, J.K. (2011). City of gods: Ilé-Ifê in time, space and the imagination. University of California Press.

Palacio, R. (2002, June 23). Balliceaux; a poem. Poets of Seine Bight Village: young poets of the Carib culture of Belize. Retrieved from http://hairounwabienbara.tripod.com/BALLICEAUX.htm

Pector, E.A. (2002). Twin death and mourning worldwide: A review of literature. Twin Research and Human Genetics, 5(3), 196-205. https://doi.org/10.1375/twin.5.3.196 
Peraldo, E. (2012). “Two broad shining eyes": Optic impressions and landscape in Robinson Crusoe. Digital Defoe: Studies in Defoe and His Contemporaries, 4, 17-30. Retrieved from https://english.illinoisstate.edu/digitaldefoe/features/peraldo.pdf

Pflüg, M.A. (1998). Ritual and myth in Odawa revitalisation: Reclaiming a sovereign place. University of Oklahoma Press. https://doi.org/10.2307/20173782

Pollard, V. (2014). Black Carib to Garinagu. Caribbean Quarterly, 60(2), 127-138. https://doi.org/10.1080/00086495.2014.11671893

Privateislandsonline.com (2019) Balliceaux Island. Private Islands Inc. Retrieved from https://www.privateislandsonline.com/islands/balliceaux-island

Pugh, J. (2013). Island movements: Thinking within the archipelago. Island Studies Journal, $8(1), 9-24$.

Pulsipher, L., \& Goodwin, C. (2001). 'Getting the essence of It': Galways Plantation, Montserrat, West Indies. In P. Farnsworth (Ed.)., Island lives: Historical archaeologies of the Caribbean (pp. 165-203). University of Alabama Press.

Reilly, M.C. (2019). Archaeology below the cliff: Race, class, and redlegs in Barbados sugar society. University of Alabama Press. https://doi.org/10.1007/s41636-020-00254-4

Rojas, I. (2013). Australian mythscape and national identity: Re-imagining Australia. Creative Approaches to Research, 6(2), 22-32. https://doi.org/10.1177/1440783314550057

Sheller, M. (2002). Consuming the Caribbean from Arawaks to Zombies. Routledge. https://doi.org/10.4324/9780203417942

Tate, S.A., \& Law, I. (2015.) Caribbean racisms: Connections and complexities in the radicalization of the Caribbean region. Palgrave Macmillan.

Taylor, C. (2012). The Black Carib wars: Freedom, survival and the making of the Garifuna. Signa. https://doi.org/10.14325/mississippi/9781617033100.001.0001

Tilley, C.Y. (1994). A phenomenology of landscape. Berg.

Tolias, G. (2013). The politics of the isolario: Maritime cosmography and overseas expansion during the Renaissance. Historical Review, 9, 27-52. https://doi.org/10.12681/hr.287

Tutter, A. (2016). Prologue: Give sorrow words. In A. Tutter \& L. Wurmser (Eds.), Grief and its transcendence: Memory, identity, creativity (pp. xxv-xxxlx). Routledge. https://doi.org/10.4324/9781315748535

Van Gennep, A. (1960). The rites of passage. Routledge, Keegan and Paul.

Vannini, P. (2011). Constellations of ferry (im)mobility: Islandness as the performance politics of insulation and isolation. Cultural Geographies, 18(2), 249-271. https://doi.org/10.1177/1474474010397597

Vizenor, G.R. (Ed.) (2008), Survivance: Narratives of native presence. University of Nebraska Press.

Vizenor, G.R. (1998). Fugitive poses: Native American Indian scenes of absence and presence. University of Nebraska Press. https://doi.org/10.2307/1184820

Volkan, V.D. (2017). Immigrants and refugees: Trauma, perennial mourning, prejudice and border psychology. Karnac. https://doi.org/10.4324/9780429475771

Zahavi, D. (2003). Husserl's phenomenology. Stanford University Press. 